\title{
Land reclamation in Egypt: A study of life in the new lands
}

\author{
Hanne Kirstine Adriansen \\ Danish School of Education, Aarhus University, Tuborgvej 164, DK-2400 Copenhagen NV, Denmark
}

\section{A R T I C L E I N F O}

\section{Article history:}

Received 27 August 2007

Received in revised form 10 May 2009

\section{Keywords:}

Egypt

Land reclamation

Desert development

Empowerment of women

\begin{abstract}
A B S T R A C T
For decades, Egypt has tried to increase its agricultural area through reclamation of desert land. The significance of land reclamation goes beyond the size of the reclaimed area and number of new settlers and has been important to Egyptian agricultural policies since the 1952-revolution. This paper examines from a micro-perspective, the life of Egyptians resettled in the new lands. The first part of the paper provides an introduction to the discourses of land reclamation, to the policies of reclaimed land distribution, and to the background of the settlers. The second part is based on fieldwork in a village in the new lands; it is inhabited by graduates who have received land under the Mubarak Project. The analysis shows that they move there in hope of making a better life especially for their children. Nevertheless, the settlers have difficulties building a sense of belonging to the new villages, and lack of good schools and other public services may cause families to split up. For some, however, resettlement in the new lands entails new social and economic possibilities. The paper concludes that while land reclamation may not be ecologically or economic sustainable, the new lands provide settlers with new opportunities.
\end{abstract}

(C) 2009 Elsevier Ltd. All rights reserved.

\section{Introduction}

After the 1952-revolution ${ }^{1}$, increased agricultural production through horizontal expansion i.e. through reclamation of desert lands was declared to be among the most important objectives of the Egyptian Government (Meyer, 1978; Wolff, 1993). Since then, land reclamation has been used for a number of different policy purposes and reclamation of the desert continues, despite the inherent problems in resettling people and cultivating the desert. Land reclamation in the Egyptian context means converting desert areas to agricultural land and rural settlements. This is done primarily by 'adding water' i.e. by extending the water canals from existing agricultural land into the desert, but also by working with the soil, ploughing in manure in order to enhance its fertility, and finally by providing the infrastructure for making new villages. ${ }^{2}$ The principal purpose was and still is to increase the agricultural production and 'overcome Egypt's overwhelmingly unfavourable population to land ratio' (Springborg, 1979, p. 54). This is both the official discourse of the Ministry of Agriculture and Land Reclamation and

\footnotetext{
E-mail address: hkoa@dpu.dk

1 The revolution in 1952 was lead by the Free Army Officers and partly driven by the discontent with the monarchy and the rich land-owning Pasha class as well as the increasing rural poverty (Bush, 2007). It was therefore not surprising that land reform was at the heart of the President Nasser's actions.

2 It should be noted that desert land has also been used for making new towns or cities, both in the shape of suburban neighbourhoods dominated by housed such as 6th of October east of Cairo and in the shape of real industrial cities such as Medinat Sadat (Sadat City) north-east of Cairo on the desert highway to Alexandria. These are not land reclamation projects initiated with an agricultural intention such as those analysed in the present paper.
}

the lines of reasoning found in much literature (e.g. Ibrahim and Ibrahim, 2003). It is argued that with a growing population there is a pressure to increase the agricultural production and it is not enough to bring more intensive means of cultivation into practice horizontal expansion is necessary. The arguments are supported by descriptions of how the waters of the Nile meander through the country leaving a green ribbon in the desert land. Except from the delta and the Fayoum oasis, only a narrow strip along the Nile is cultivated and the population is also concentrated in these areas. Only about 4\% of Egypt's total area is agricultural land and this area has one of the highest population densities in the world. Seen from this perspective, reclamation of the desert appears 'natural', almost inevitable in light of the population growth and increased congestion in the so-called old lands - these are the lands in the Nile Valley and the delta. Mitchell (1995) shows how this visual - often poetic imagery of the country obscures and simplifies the relationship between the economic and social spheres as well as the involvement of international actors. Nevertheless, land reclamation remains high on the agenda of the Egyptian Government and is supported directly or indirectly by international agencies (Bush, 2007). Therefore, it is relevant to address the issue of land reclamation, and, taking Mitchell's arguments into account, the new lands are analysed in the context of social and economic interactions and reference is made to the involvement of international actors in this process.

Most of the literature on land reclamation in Egypt concerns macro-scale implications of this type of intervention. Especially agro-ecological consequences of cultivating the desert and the problems of ensuring sufficient and sustainable water and energy supply have been discussed (e.g. Enien et al., 2000; Kamel and Dahl, 2005; Lenny et al., 1996; Monem et al., 1998). Fewer studies con- 
cern land reclamation in a socio-economic perspective (e.g. Voll, 1980), although some researchers touch upon the cost-benefits of large reclamation projects such as Toshka (e.g. Ayeb, 2002; Bush, 2002c, 2007) and this issue is debated both in parliament and in newspapers (El-Din, 2000; El-Din, 2006; El-Sayed, 2007). Nevertheless, studies of the new villages and their inhabitants are rare, and remarkably few have carried out fieldwork in the new communities (exceptions being Hopkins et al., 1988; Meyer, 1994, 1998).

The present paper has a dual purpose: first, it attempts to provide an overview of public, post-revolution land reclamation in Egypt with special emphasis on the Mubarak Project initiated in 1987. Second, it redirects the discussion to the micro-perspective providing insight into life in villages with the Mubarak Project. In doing so, the paper raises questions regarding the challenges and opportunities in the new villages with emphasis on women's points of view. These issues are addressed by dividing the paper into five main sections: first, an introduction to the discourses of land reclamation in Egypt is provided. The second section outlines policies of distributing reclaimed land; both these sections are based on existing literature and key-person interviews. The third section is an introduction to the case study; this includes a description of the Mubarak Project and of fieldwork in the Mubarak villages. In the fourth section, life in the new lands is analysed. This is done by focussing on four issues: motives for resettling, building a sense of belonging, women in the new lands, and finally opportunities and challenges. Finally, there are is a discussion and some concluding remarks.

\section{Discourses of land reclamation}

In 1950 Ahmed Hussein, the minister of Social Affairs, suggested a plan labelled the 'Five Feddan ${ }^{3}$ Scheme' aiming at distributing reclaimed desert land to landless peasants (Johnson, 2004). Hussein gained international recognition for his work the Rural Social Centres. The 'Five Feddan Scheme' was a part of his plans for reform of the Egyptian countryside including a minimum agricultural wage and limited land distribution. Hence, the development of the countryside was already important in the discourse prior to the 1952revolution.

After the revolution, land redistribution was an important goal, but land reclamation was also on the agenda. The driving force behind post-revolution land reclamation was the commitment of new regime to help the rural poor as well as the need for more agricultural land mainly due to the increasing population (Meyer, 1978; Voll, 1980). These arguments have been repeated and supplemented with statistics showing how the arable land-to-man ratio has declined. FAO, for instance, indicates a decline of more than 75\% from 1897 to 1999 (FAO n.d.) and this trend continues according to the latest FAO statistics (FAO, 2006). However, researchers such as Mitchell (1995) and Bush (2002b, 2007) have contested the reasons for an expansion of the agricultural area and hence the need for opening the desert. They argue that these policies should be understood as part of the wider political manoeuvring of both the Egyptian Government and its influential international partners such as USAID. The Government's focus on land reclamation, for instance, has removed the focus from the importance of land redistribution and the management of the old lands (Bush, 2002b). Another example is the country's increased reliance on animal production at the expense of plant production, which in turn has lead to increased import of wheat from the US (Mitchell, 1995). As explained by Saad: 'Agriculture has always been central to Egypt's economy and its politics. The agricultural sector has often been an arena of conflict that goes beyond the countryside' (Saad, 2002, p. 103).

\footnotetext{
${ }^{3}$ One feddan is 0.42 hectare.
}

It is beyond the scope of the paper to go into detail with the arable land situation in Egypt, as the magnitude of the land availability problem does not explain Egypt's obsession with desert reclamation. ${ }^{4}$ As pointed out by Holmén (1991), the scope of land reclamation has varied over the years; and it has been used as a remedy for almost any problem. One example is that after the UN Convention to Combat Desertification from 1994, some of Egypt's land reclamation projects have been carried out under the pretext of combating desertification - and supported financially by the International Fund for Agricultural Development (IFAD, 2000). Furthermore, expansion of the irrigated area in the desert is part of the Egyptian National Program to combat desertification (UNCCD, 2005). Since the early 1990s, the Egyptian government has emphasised desert community ${ }^{5}$ development more than just land reclamation. This is yet another example of how the purposes of land reclamation vary. It implies that the concept of land reclamation is broadened to include planning and development of 'integrated rural communities' in the new lands in order to overcome the problems of unemployment, congestion, and shortage of housing in the 'old lands'. Hence, reclamation policies are increasingly being linked with broader development policies (El-Zoghby, 1999; Erian, 1997). The Mubarak Project, which would have been virtually non-existent without development aid from a number of countries and international organisations, e.g. Danida, EU, and World Food Programme, is an example of this and will be discussed in the following.

These are just a few examples of how land reclamation is represented as a remedy for all sorts of problems and how it serves multiple political purposes. Present-day land reclamation in Egypt can be seen as having four policy objectives ${ }^{6}$ : to enhance agricultural production - the historical motive for reclamation; to decrease population growth in the Nile Valley and the delta; to generate employment; and finally to alleviate poverty. Hence, there are various reasons for opening the desert, and the reclamation policy of new lands continues despite the problems involved in resettling people and cultivating the desert. But who are the people inhabiting these new lands and why did they end up there? This is the issue of the next section.

\section{Policies of reclaimed land distribution}

The land reforms in the 1950s and 1960s redistributed about $12 \%$ of Egypt's agricultural land, thereby providing land to the country's landless (Bush, 2007). Before the revolution, $0.1 \%$ of the landowners owned $12 \%$ of the arable land and $75 \%$ of the landowners owned less than $13 \%$ of the arable land, owning less than 1 feddan (0.42 hectare) each (Bush, 2004). While these reforms managed to redistribute land and played an important role in reducing rural poverty, the reforms were like similar agrarian reforms in other developing countries largely gender-blind (Razavi, 2007). While numerous publications have been written on the reform and so-called counter-reform of the Egyptian countryside, little has been written on the distribution of reclaimed desert lands. Saad notes that by analysing how reclaimed lands have been distributed, insights are given into political practice in contemporary

\footnotetext{
${ }^{4}$ Please refer to Ibrahim and Ibrahim (2003) for a recent account of Egypt's agricultural economy.

5 With reference to Egypt's old lands, Saad has argued that the concept 'community' is ambiguous and that community '... has no local equivalent in the village' (1998, p. 37). She explains that the concept obscures the multiple levels of identity and belonging found in villages and further that 'community' often is seen to correspond with a physical boundary of human settlement with a unified collective interest that is not found 'in reality'. Therefore, the concept community is used sparingly in the present paper. When used, it is with a human geographic conceptualisation in mind as 'a social network of interacting individuals, usually concentrated into a defined territory' Johnston, 2000, p. 102.

${ }^{6}$ Interview with Dr. Tutwiler, director at the Desert Development Center, The American University in Cairo.
} 
Egypt' (Saad, 1999). Other researchers have pointed out that the Government uses the new lands and especially the distribution of land to care for and win political support from certain groups of people (e.g. Springborg, 1979; Bush, 2002c). The way reclaimed land is distributed and owned can best be understood in the wider context of rural development in post-revolution Egypt.

The creation of the Tahrir province (halfway between Cairo and Alexandria) in 1954 was the first reclamation project of desert lands after the revolution. Reclamation of the desert really took off in the 1960s and since then, a number of different groups have benefited both from different government programmes and from projects run by private investors. The history of reclamation is characterised by the development of large state farms with thousands of workers in the 1960s, inspired and partly financed by the Soviet Union (Springborg, 1979); and by the subsequent failure of these projects and various attempts to subdivide the land between the workers in the 1970s. This means that in the older reclaimed lands, many of the inhabitants are small farmers ${ }^{7}$, former workers from the state farms (Meyer, 1978, 1995).

From the 1980s, a new group of people began to settle in the reclaimed desert; these were graduates. In order to understand where the graduates came from, we have to look back to the 1960s when education became a social reproduction strategy for rural households (Bach, 1997). With free education, decreased need for (child) labour in the fields, and the state's employment guarantee to graduates, education was seen as an attractive possibility for young rural dwellers - including girls - and the educational level of rural Egypt augmented significantly. In the 1980s, however, it became increasingly difficult to find employment for all the graduates; and since the mid 1990s, when the Government officially gave up the employment guarantee there has been a high rate of unemployment among graduates, especially among those living in rural areas (Bach, 1998). This 'educated unemployment', a mismatch between higher education output and labour market requirements, has also been pointed out by the Arab Human Development Report as one of the problems in contemporary Arab societies (UNDP, 2003). In order to counter this development, the Egyptian Government initiated schemes for granting graduates reclaimed land. In the 1980s, only graduates with an agricultural degree were qualified, and these graduates were seen as the backbone of promoting productive desert farming. With the increasing unemployment, however, all graduates were eligible, and the Government declared land reclamation schemes a means to reduce rural poverty and inequality.

In the 1980s, liberalisation of the Egyptian countryside began. This was promoted by the Minister of Agriculture, Yussef Wali and supported by the USA, the World Bank and IMF. The liberalisation caused an end to state provision of agricultural inputs and marketing, and it effectively revoked tenants' tenure rights which had been ensured through Nasser's rural reforms a few decades earlier (Bush, 2007). In the late 1990s, rural Egypt was heavily affected by the Economic Reform and Structural Adjustment Programme, ERSAP. ${ }^{8}$ Especially the effects of the 'Owners and Tenants Law' of 1992 were severe for large parts of the rural population. This law, called Law 96 of 1992, was effective from 1 October, 1997 after a five year transition period. The law changed tenure regulations so tenants have to

\footnotetext{
${ }^{7}$ The rural economy of Egypt is often described as a peasant economy and the inhabitants as peasants or fellahin (e.g. Dyer, 1991; Seddon, 1986; Glavanis and Glavanis, 1983). Mitchell (1998b), however, argues that the peasant nomenclature often used for villagers with small holdings seem to escape the complexity of the lives of many small holders and we need to reconsider our identity labelling and whole understanding of the rural sector in Egypt. Keeping these arguments in mind, the terms 'graduates', 'small farmers', and 'landless/tenants' are used. These terms are used by other researchers of rural Egypt (e.g. Hopkins, 1997; Mitchell, 1998a) and they encompass the majority of the new settlers.

${ }^{8}$ The ERSAP was launched in March 1990 and consisted of a number of different components (See Abdel-Khalek, 2002).
}

Table 1

Public post-revolution land reclamation and beneficiaries.

\begin{tabular}{|c|c|c|c|}
\hline Year & Group & Number of beneficiaries & $\begin{array}{l}\text { Feddan ( } 1 \text { feddan } \\
\text { is } 0.42 \text { hectares) }\end{array}$ \\
\hline \multirow[t]{4}{*}{$1952-60$} & Graduates & 12 & 333 \\
\hline & Small farmers & 822 & 5788 \\
\hline & Others $^{\mathrm{a}}$ & 43 & 4636 \\
\hline & TOTAL & 877 & 10,757 \\
\hline $1960-80$ & TOTAL (Graduates) & 1015 & 24,705 \\
\hline \multirow[t]{4}{*}{$1981-86$} & Graduates & 1098 & 10,095 \\
\hline & Small farmers & 3119 & 16,847 \\
\hline & Others & 587 & 3361 \\
\hline & TOTAL & 4804 & 30,303 \\
\hline \multirow[t]{5}{*}{$1987-2003^{b}$} & Graduates & 45,834 & 230,000 \\
\hline & Evicted tenants & 16,727 & 43,000 \\
\hline & Small farmers & 4569 & 30,041 \\
\hline & Others & 2833 & 40,232 \\
\hline & TOTAL & 69,962 & 343,323 \\
\hline
\end{tabular}

Source: (MALR, 2003).

a Others are for instance retired government employees or families of military personnel.

b All with the Mubarak Project.

rent land at free market prices, which are ten times as high as the previously fixed prices (Müller-Mahn, 1998). The law has had a significant impact on rural life in the old lands, where tenancy is most common; and the effects have been widely discussed (see Bush, 2007 as well as several contributions in Bush, 2002a; and in Hopkins and Westergaard, 1998). In many areas, market liberalisation has caused rural poverty and made poor rural inhabitants even more dependent upon help from their relatives (Bush, 2004). Many tenants could not afford the new leases and ended up landless. In order to counter some of the negative effects, the Government's reclamation schemes were opened to this group - the landless, former tenants who became evicted from the old lands after the land reforms. The possibility of acquiring new land seemed promising for rural dwellers hit by the reforms, although few were aware of the option. Moreover, there was a discrepancy between the potential number of applicants and the number of beneficiaries, and the eligibility criteria made it impossible for the majority of the evicted tenants to make the most of the opportunity to get new lands. Finally, it has been mentioned that those who received land did not have the investments necessary for making the land profitable (Bach, 2002; Bush, 2002c; Saad, 1999).

As Table 1 shows both graduates and evicted tenants have been granted land within the Mubarak Project. This was initiated in 1987 and still has a high profile in the Ministry of Agriculture and Land Reclamation. The project relies on development aid from a number of countries and organisations. A closer look at the Mubarak Project can provide insights into the construction of new rural communities. The Mubarak Project has attracted little scholarly attention and the few accounts are fairly bleak (Meyer, 1998). It was, however, the following remark that fuelled my curiosity for the Mubarak Project: '... to allocate land to graduates with the 'Mubarak Project' has been disastrous' (Bush, 2002b, p. 25 ). While it is possible that the ecologically and economic consequences of the land reclamation schemes may be negative, there is a need for field-based research of the villages and their inhabitants in order to understand what they make of their new life.

\section{Constructing new rural villages: The Mubarak Project}

\subsection{The Mubarak Project}

The majority of the reclaimed land for the Mubarak Project is located on the Western side of the delta and received water through 
irrigation canals from the Nile. As seen in Table 1, the number of settlers with the Mubarak project is app. 70,000 plus their families, app. 17,000 of these are former tenants. The project is also responsible for distributing land from the Toshka land reclamation scheme to approximately 500,000 new settlers plus their families and to the same number of people in other so-called mega reclamation projects all over the country (K. Sherif, MALR, pers. comm.). This is why the rationale and outcome of the Mubarak Project have bearings beyond the number of graduates and tenants settled so far.

The Ministry of Agriculture and Land Reclamation (MALR) states that the rationale underlying the Mubarak Project is that graduate unemployment can be solved by granting the graduates reclaimed land. When a group of graduates with different educational background is brought together, integrated rural communities can be developed. Here the human capital of the youth can be used for developing villages in the reclaimed lands and increase the agricultural productivity by adopting new technology. Subsequently, this will alleviate the population density in the delta region and attract investors, small farmers, and auxiliary workers to the new lands - and this means that increasingly more desert can be reclaimed (MALR, 2000, p. 5). The graduates respond to announcements in the newspapers and if they are found eligible, they are allotted 5 feddan of desert land and a 1-bedroom house in the adjacent village. When they receive it, the land is equipped with an irrigation system. For the first five years there are various means of aid until the land can be expected to provide an output, which can sustain the family. In this way, the Mubarak Project is very similar to Ahmed Hussein's 'Five Feddan Scheme' from $1950 .{ }^{9}$ According to the ministry, land is granted on the basis of the following criteria (MALR, 2000):

- Age (applicant should be under 30 years old)

- Qualification (agricultural degrees are preferred, but all graduates can apply ${ }^{10}$ )

- Graduation year (recently graduated applicants are not considered)

- Gender (men are preferred, but women can also apply)

- Origin (applicants from rural areas are preferred)

- General and agricultural background

A total of 100 point can be given for fulfilling these criteria. For instance, agricultural degrees are worth 10 points and other degrees 5 points, the gender criteria gives men 10 points and women 5 points. An administrator of the Mubarak Project explained that they were afraid that women would become absentee landowners, because their husbands did not want to live on their land, therefore women are given fewer points and unmarried women were preferred (K. Sherif, MALR, pers. comm.). Furthermore, candidates are expected not to have a criminal record, and the applicant should have finished military service or public service or have been exempted. Finally, applicants working in the government or public sector cannot be granted land and by accepting land, the graduates renounce their possibility to public office.

Because of the need to help evicted tenants after the land reforms, some of the Mubarak graduate villages have been converted into tenant villages. However, there are some modifications. Originally built for graduates, the holdings had a size of 5 feddan, but the government decided that the evicted tenants should only receive 2.5 feddan. This means that 2 families had to share the land and the house intended for one graduate family. The Mubarak Project

\footnotetext{
${ }^{9}$ For more information about his scheme, please refer to Johnson, 2004.

10 Most degrees seem to be recognised. The only exception I have found is that graduates from the religious university Al-Azhar are refused on the grounds that they are guaranteed a position within the religious system.
}

soon realised that sharing houses was a bad idea and supplementary accommodation was built in the tenant villages. ${ }^{11}$ According to the administrators of the Mubarak Project, the reason for granting the evicted tenants smaller plots were both to be able to help more people and that tenants had different skills and knowledge compared to the graduates, i.e. were not as able to cultivate a 5 feddan plot ( $\mathrm{K}$. Sherif pers. comm.). It can be argued, however, that by granting the former tenants smaller farms inequalities are reproduced.

Based on studies of a number of different settlement projects all over the world - also in Egypt - Scudder (1991) shows that new settlements have to go through a number of phases before they can be considered 'mature' and that this has bearings for the way he evaluates such settlements. According to his model, the development process consists of four phases: I Planning, initial infrastructure development, and settler recruitment; II Transition; III Economic and social development; IV Handing over and incorporation (Scudder, 1991, p. 160). As Scudder notes, in reality these phases overlap and phase three and four may be reversed. In order to be 'mature', new land settlement must pass through all four stages. None of the villages under the Mubarak Project have existed long enough to have been through all four phases and to be considered 'mature' in Scudder's terms. As land reclamation has been ongoing since the 1950s, there are villages old enough to have passed through all four phases. Hopkins et al. (1988) conducted fieldwork in a number of villages in South Tahrir, the first of the reclaimed desert lands ${ }^{12}$. In the rich material from their fieldwork in the new lands, they found many contradictions: 'as people at different points in the system perceive it differently' (Hopkins et al., 1988, p. 115). Nevertheless, Hopkins' study provides an important perspective when trying to understand the development of the new villages and attempting to access the 'maturity' of new settlements. Perceptions of life in the new villages vary not only from one person to another but also with time. Many of the initial problems experienced should be alleviated when a settlement passes through all four phases. Fig. 1 shows the location of the new lands and the study area.

\subsection{Fieldwork and the Mubarak communities}

Fieldwork was carried in the new lands and combined with key person interviews in Cairo on six occasions, app. 5 months from 2002 till 2006. Access is a problem in the new lands. ${ }^{13}$ In order not to limit myself to easily accessible members of the villages such as member of the agricultural cooperatives, a number of different methods were used to get in contact with interviewees. First, I participated in an agricultural training course with participants from ten villages under the Mubarak Project (hereafter called the fieldwork villages); eight graduate villages and two tenant villages. ${ }^{14}$ During the three-week, full-time course, I participated in the training and social activities of the trainees and made interviews with men and women, village-based focus-group interviews, as well as participatory observations. My participation in this training course provided me with access to the villages. They are located on the Western side of the delta on both sides of the desert road between

\footnotetext{
11 It should be underlined that 'tenants' in this context refers to dispossessed tenants who have been granted land under the Mubarak Project. Hence, today they are landowners in the new lands, formerly tenants in the old lands. Likewise, a 'tenant village' is a village under the Mubarak Project made for the dispossessed tenants.

12 In the Egyptian context, there are old new lands, i.e. the first post-revolution reclaimed lands such as Tahrir, and new lands, which roughly can be characterised as the areas reclaimed under President Mubarak.

13 My fieldwork was further hampered by political developments, first by the outbreak of the war against Iraq in 2003 and second by the 'cartoon crisis' following the publication of cartoons of the Prophet Mohammed in Danish newspapers in 2005. These events meant that my local partners hesitated to let me carry out fieldwork and sometimes would only let me do so with an escort.

14 The names of the villages and their inhabitants are omitted as the interviewees were promised complete confidentiality.
} 
Cairo and Alexandria, near Sadat City (see Fig. 1). These villages are of recent origin, established between 1988 and 2002, and can all be characterised as belonging to the new, new lands. All the villages are established to serve the agricultural sector and despite the diversification of production activities, life evolves around agriculture. As all settlers in a certain village have been granted land at more or less the same time, they also move in at more or less the same time, usually within the same year. In terms of planning, the villages are fairly alike; although they vary in size from 1500 to 10,000 inhabitants, with a population of 6000 being the most common. From the outset, all houses are identical and are located on a grid. In the centre of the village, shops, schools, mosques and other parts of the common infrastructure can be found. The fields surround the village, and some inhabitants live several kilometres away from their fields. As the settlements are located in the desert, vegetation is non-existent in the newest villages, but the older villages have escaped their desert appearance and the monotonous houses have gained some individuality.

Upon visiting all of them, I chose one graduate village from 1994 for in-depth fieldwork; this was the one where I had the best

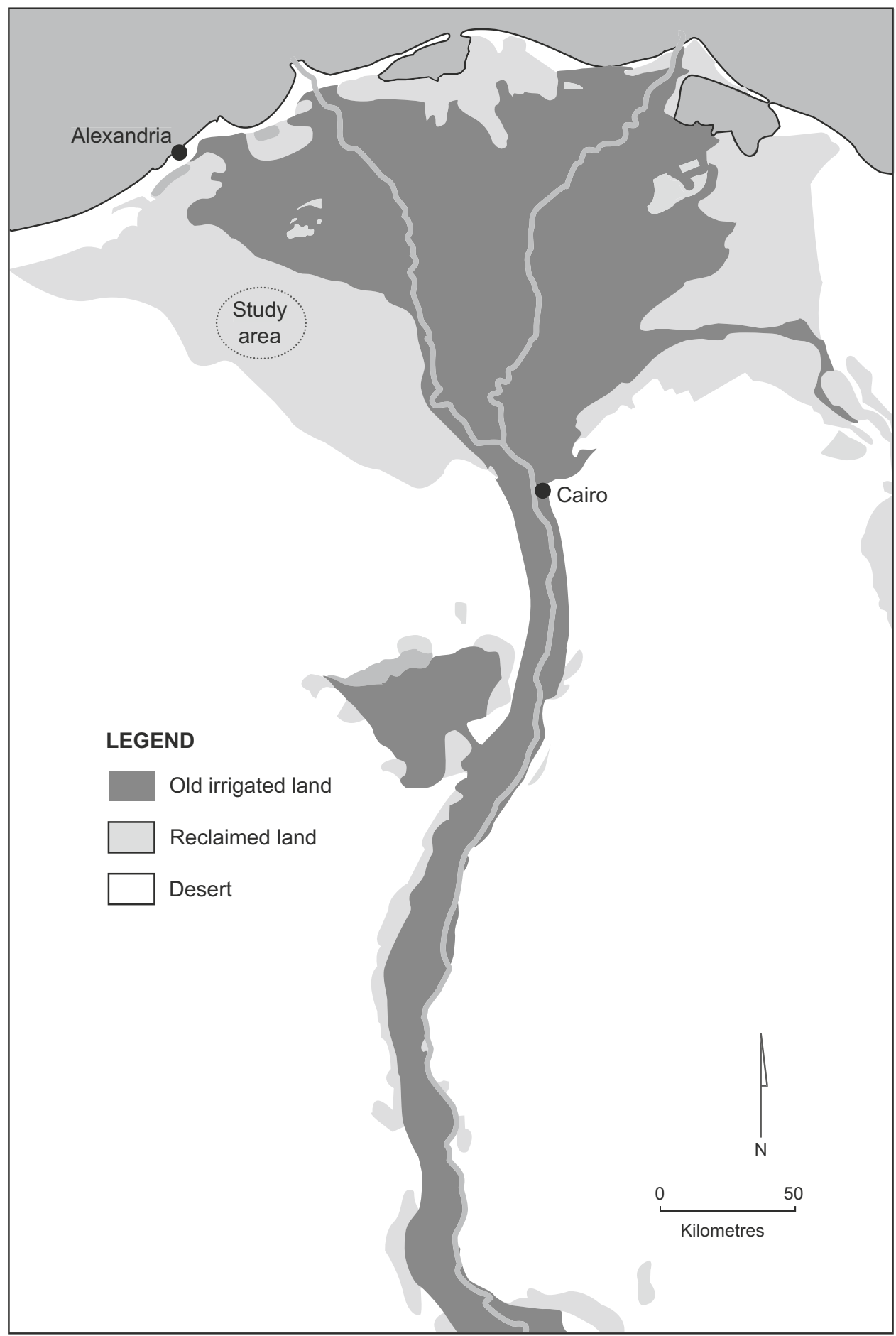

Source: Danish Institute for International Studies

Fig. 1. Map showing reclaimed areas and the location of the study area. 
contacts. Here I relied on the people from the training course with whom I had established confidence. They gave me access to other people and by employing a snowball technique I got to know villagers who had arrived outside the Mubarak Project. Often this meant people who had arrived after the graduates and who were tenants in some way - some of them illegally. They did not have the same access to the services in the village and were generally less educated and poorer than the graduates. As my interest was the construction of life in the new villages, the intention was not to construct a reliable scientific sample of informants, but to get a picture of the various 'ways of life' and stories for ending up in the villages. Moreover, as access was difficult, especially to people 'outside' the Mubarak Project, I relied on qualitative information gathered through interviews and participatory observations rather than restricting myself to data that could be analysed numerically. During the four-year period that I visited the villages, I collected a wealth of qualitative material through informal conversations, participation in on-location training courses, participatory observations in the village, the school, and the fields, as well as in-depth interviews and focus group interviews.

My first walk through the streets of a graduate village left me with a peculiar feeling of something missing, it was very quiet and only few people were seen in the streets. After observing village life for a while, the heterogeneous demographic composition became obvious. The most striking was the lack of old people. Wen (1979) has pointed to the effect of demographic composition for settlement building. He notes that 'the predominance of a certain age group, male or female, may create problems of family relations and household maintenance' (1979, p. 37). This leads him to suggest that the selection criteria should account for different age groups, occupations, and roles that are important for a sustainable settlement. As it has been shown, the Mubarak Project did not aim at an even demographic composition. However, the predominance of certain age and social groups were not mentioned by the interviewees.

\section{Life in the new lands}

The following analysis of life in the new lands is focused around four main issues: motives for resettling, building a sense of belonging, women in the new lands, and opportunities and constraints. This is not an exhaustive account of life in the new lands, but an illustration of the most pertinent issues I uncovered during my fieldwork.

\subsection{Motives for resettling}

Why do people leave their homes and move to the desert in the first place? During the many interview and conversations, different answers came up. Some of the interviewees explain that the Government tries to make 'greening of the desert' a national project that everybody should feel obliged to participate in. Hence, some see their participation in the Mubarak Project as a way to serve their country. Also, many of the male interviewees had a farmer identity and expressed pride in participating in 'greening the desert'. Others feel encouraged by the Qur'ân, where they claim migration to the desert is justified in Sûra 4 (95-100), which they quote. ${ }^{15}$ This

\footnotetext{
${ }^{15}$ Here, the quotes are from Abdullah Yusuf Ali's translation of the Qur'ân into English (The Holy Qur'an: text, translation and commentary):95. Those people among the believers, who stay at home without any genuine excuse, are not equal in rank with those who exert their utmost with their lives and wealth in GOD's cause. For GOD has assigned a higher rank to those who do not stay at home. Although GOD has promised a rich reward for all, He has a far richer reward for those who fight in His cause than for those who stay at home.100. He who forsakes his home in the cause of God, finds in the earth many a refuge, wide and spacious: Should he die as a refugee from his home for God and his Apostle, his reward becomes due and sure with God: and God is oft-forgiving, most merciful.
}

may well be reasons given in the local mosque. However, quotes from the Qur'ân are also used by the Government. The following quote is found on the inner page of a booklet, 'The Mubarak Project', published by the Ministry of Agriculture and Land Reclamation (MALR, 2000):

"Thou seeth, Among His Signs. The Earth, as it is prostrated, But Once we make rainfall on it. It revives, and turns green once more. Almighty who renders her alive, Resurrects the mortals. His power controls every thing". ${ }^{16}$

This could be interpreted as an indication of how the Government of Egypt has adopted the language of the Islamic discourse. The Government may well have done this in order to curb the Islamist opposition, which has been the greatest threat to the regime since the mid-1970s.

Both the national and the religious discourse provide a "valid reason' used by the interviewees to explain their move in general terms. However, these discourses are not always part of the narratives found at the individual and family level. Many interviewees explained that the Mubarak Project was their only possibility to become landowners and that there was nothing in their original village to make them stay. Although there are a number of different reasons why people move to the reclaimed lands, landownership seems to be a major attraction. Related to this was the possibility to give their children a good start in life - something that land ownership and the new lands seemed to represent.

The majority of the interviewees had positive expectations regarding life in the new lands. There was consistency on issues of importance for establishing a 'good life'. Many of the interviews reflected the duality of the desert; while representing the empty, remote, and marginal land, the desert also signified space, quiet, and cleanliness. This is in contrast to the old lands, which are described as crowded, dirty, stressful, and noisy. A female graduate had come to live in the Mubarak village as a divorcee with her son. She explained that she felt more at ease in the new village and even though she preferred when her brother kept her company, it was not a problem to live in the village on her own:

"Now I feel this is my place, it is better for me to live here than moving back to my family [in the delta]. My psyche feels better here. Of course the services in the delta are better, but the most important thing is peace at mind and that I have here. Also it is better for my son here, he utilises the whole area. I'm from the most densely populated area; there are far too many people there".

A wage labourer, who lived with his family in the old lands while working in the new lands said:

"If the school was better, I'd stay here all the time with my family, because here the weather is nice, there is space and peace of mind".

The following statement came from a woman in an evicted tenant family who had lived in the new lands for four years:

"The weather is nicer, it is peaceful and quiet and now when I go back [to the old lands], I miss this".

Hence, when talking about the positive aspects of living in the new villages, there were three responses that came up in almost every conversation: There is space, the air is clean/the weather is nice, and it is peaceful and quiet. Furthermore, for quite a few their relocation to the desert had involved a higher material standard of living, especially a bigger house. The interviewees valued all four

\footnotetext{
16 The quote is taken directly, including errors, from the booklet. It refers to Sûra 39
} 
aspects highly in regard to bringing up children, and the new lands were seen as a 'space of opportunity' for giving children a good start in life. ${ }^{17}$

\subsection{Building a sense of belonging}

While it may be easy to find motivation and justification for moving to the desert, some have difficulties feeling at home there. In order to understand the processes influencing settlement building and the construction of 'feeling at home' in the new villages, the concept 'sense of belonging' can be used. The concept is often linked with issues such as the construction of space (desert) into place (settlements) ${ }^{18}$, territorial belonging, and identity (e.g. Ansell and van Blerk, 2007; Bushin et al., 2007; Crang, 1998; Tuan, 1977). With regard to more local-scale processes, however, the concept is related to ideas of constructing 'place' and 'home' (Morley, 2001) and it can be valuable for understanding processes of land claims, attachment to certain areas, and even farming behaviour. The concept has a common-sense air to it that is valuable, because this is also what people themselves express during interviews touching upon this issue. However, it is useful to note that a sense of belonging is 'inevitably complex, filtered as it is, and frequently reworked, through sedimented layers of memory and lived experience, shaped by the intangible intimacies of history and the pragmatics of the present' (Hammar, 2002, p. 228).

While many valued the new villages as a good place for bringing up children, 'real life' turned out that some what different. Many of the settlers complained that families had to split up due to lack of services and infrastructure, for instance absence of secondary schooling. This caused a lack of belonging as well as a sense of being abandoned by the Government, which did not provide the services promised. Furthermore, the local officials such as doctors and teachers were not interested in living in the new lands. Although they were appointed to work and live there, the settlers claimed that the majority of the officials avoided staying in the new villages, neglected their jobs, and did not try to become part of the village. This led to an image of the new lands as a place not worth staying in, and alienated the settlers from constructing a sense of belonging.

People who do not feel a sense of belonging to a given community, this being spatially or socially bound, are not inclined to participate in the development of this community (EHDR, 2003). Community feeling and sense of belonging is built and negotiated at many levels. Hopkins et al. (1988) have suggested that the ability to solve problems within the village without police interference shows an increased community feeling. In all of the fieldwork villages, customary councils, so-called majlis 'urfi, had been established. The majority of the councils consist of older men or, in the graduate villages, of people with the highest degree; only in one of the villages (a graduate village), women are represented in the council. The interviewees explain that they prefer to use the customary councils in cases of conflict. Following Hopkins' idea, the construction and functioning of customary councils show that community feeling is growing in the villages. At the same time it is worth noticing that the new values and the different demographic composition are also represented in the composition of the councils. Hence, the new villages also represent new ways of organising society.

Last but not least it is worth noticing that many settlers mentioned that the new land brought them together and made a

\footnotetext{
17 Please refer to Adriansen, 2007 and Bushin et al., 2007 for more information on rural childhoods in the desert lands.

18 Space and place are key conceptual binaries in human geography. In this paper, 'space refers to location somewhere and place to the occupation of the location. Space is about having and address and place is about living at that address' (Agnew, 2005, p. 82).
}

community of them. Hence, to establish a sense of belonging to the desert villages is a process involving contradictory feelings and actions.

\subsection{Women in the new lands}

As mentioned above, the move to the new lands was accompanied with the expectation of getting a better life and new opportunities. Especially women equated the new lands with new opportunities. Here the social norms and rules of the old lands can be negotiated and redefined. Hence, by granting land to women, the 'Mubarak Project' has enabled rural women to participate actively in shaping their society.

From the outset, almost 30\% of the landowners in the village where in-depth fieldwork was carried out were women. Only single women were granted land by the Mubarak Project (K. Sherif, pers. comm.). However, due to the delay between applying for land and actually settling in the new land, some of the women were married when they arrived in the new village. Other women were not married; few lived alone, others with a family member, for instance a brother. The female landowners were asked what it had been like to arrive in the new villages as single women and what it was like to live there today. Two women in their thirties reflected:

“It wasn't a problem. We got our younger brothers to come and stay with us. And when they were not around all the women stayed together - slept and ate together".

"They used to say that women cannot make it in the new lands. They hate that women can make it on their own here. Men easily get annoyed with me and women jealous of me. It is necessary to talk in the right way and have good relations".

In the new lands, women can be involved in all types of work in the fields. This is not the case in the old lands, where tilling is perceived to be men's work and women only participate if there is a severe lack of labour. The female respondents discussed whether their work in the fields in the new lands was due to more freedom in the new lands or due to lack of male labour in the fields. It can be concluded that women have found new opportunities in the new lands; they are away from the social control of their family and family in-law, in a social environment dominated by young, educated people. As one of the landowning women explained:

"My home is my kingdom. In the delta, I only had control over a very small area. My mother in law was always there".

Similar findings have been reported by Saad (1998) and Wen (1979). Based on studies in an old village with adjacent reclaimed land, Saad found that even within the same village, different practices occurred in the old and the new lands especially with regard to women's behaviour. She concluded that '...the distance from the social control of the core community allows women more freedom outside the house' (1998, p. 32). Wen (1979) has noted that the emergence of new norms and values is common in new communities due to the change of social and physical environment that in turn often lead to the creation of new routines and institutions.

The World Food Programme has assisted the Government of Egypt's programme of land reclamation and development since 1970. The role of the WFP has been to distribute food to beneficiaries of new land, as the land does not yield enough to feed a family the first four years after settlement (WFP, 1994). Through their projects in the new lands, the WFP has tried to empower women. For instance, their food assistance has been based on the condition that men receiving land should let $20 \%$ of the property register in 
their wife's name, which means that she gets her name on the hiy$a z a .{ }^{19}$ By having her name on the hiyaza, the wife is entitled to become a member of the agricultural cooperative ${ }^{20}$, take credits and thus to participate actively in the settlement (O. Nabil, WFP, pers. comm.). This rather small step for WFP in terms of economic investment has great effect in terms of empowerment of women.

The different organisation of agricultural and social activities in the new villages also extends the field of socially legitimate opportunities. For instance, some women have started their own businesses such as growing and arranging flowers for decoration or sewing clothes. Further, one woman explained that when women participate in cultivating the fields, there is a need for somebody to take care of the children. As many of the graduate families are nuclear families and they live far away from the rest of the family, there are no grandmothers to take care of the children. This means that there is a need for kindergartens, and the involvement in the market economy makes it possible for some families to pay for child care. Some of the new (social) opportunities exist because the gender roles are lived in a new space; other (job) opportunities are due to the educational level of women in the new lands. The number of illiterates is lower and some women explain that with a degree in commerce for example, it is practicable to start a business. Here it should be noted that many of the graduate men have married women with a degree and these women also start their own businesses. Hence, it is not only the women who have been granted land, who act as entrepreneurs in the villages.

\subsection{Opportunities and challenges}

Not only do the new lands entail different roles and opportunities for women. The pattern of social differentiation is also different in the desert lands. The new villages are more homogeneous than villages in the old lands; first and foremost the old class of big landowners is not present. The homogeneity is also due to the fact that the Mubarak scheme appeals to a certain group of people - graduates. This means that the settlers are of similar social and educational background as well as of similar age and this in turn may affect the social norms in the new spaces of rurality. Several of the interviewees state that the new lands give possibilities for a diverse, some say more free, behaviour. They envisage the new lands as 'spaces of opportunity' because they can escape some of the constraints experienced in the old lands. Here, constraints should be understood both as lack of access to land and employment as well as the patterns of social rules and norms endorsing certain behaviour.

While the new lands entail new opportunities for women and children, there are also challenges associated with living in the new lands; these entail both material and emotional issues. Foremost there is a lack of services and infrastructure. This is a serious problem especially in the newer villages where they need clean drinking water, reliable health clinics, and schools above primary level. This has important consequences for the population. For instance, unreliable provision of electricity and lack of maintenance of the water pumps make the farmer more vulnerable and increase the production costs. The shortage of clean drinking water makes people sick. Some families have simply split up and left their children with relatives in the old lands because the children were con-

\footnotetext{
19 A hiyaza is a contract of land ownership or permanent tenancy. Nasser's agrarian reforms meant that rent contracts were fixed on a permanent basis - a so-called hiyaza - that could be inherited. When a tenant became a hiyaza holder, it meant that he could benefit from the services of the agricultural cooperatives and take credits (Müller-Mahn, 1998)

20 Prior to the structural adjustment programme, agricultural cooperatives more or less controlled agricultural growth by providing agricultural inputs and marketing outputs. Agricultural cooperatives were also established in the new villages (Bush, 2004).
}

sidered too fragile to stay in the new villages. This causes a feeling of loneliness, which was accentuated by the fact that many of the graduates live in nuclear families, in contrast to the old lands, where most people live in extended families. Many graduates mentioned that they missed the family they had left behind. This complaint was also aired by graduates who had lived in the new lands for more than ten years, which means that it is not only a matter of 'getting used to' the new place as discussed in the previous section. These issues are naturally interrelated. One example is that the feeling of loneliness is accentuated if the services and infrastructure are poor; if, for instance, there is no public phone or poor means of transportation.

The major challenge, however, is that agriculture in the new lands is very demanding in terms of initial investments. Obviously, the desert soil is of poor quality and therefore the yields are low. Profitable production takes years and can best be obtained by planting, for instance, grapes or citrus trees. However, these crops do not provide the farmer with any income during the first seasons, and the first step towards successful desert farming is consequently savings or loans, both of which are rare among the settlers. To quote one of them: "Desert development is long term, but we can only afford short term". Although the settlers can wait five years paying for the land and there are different types of loans, many feel they have been caught in a trap where they cannot make the land profitable and they cannot go somewhere else. One man explained that he preferred a government job, where he would have health insurance and retirement benefits. He explained that he was religious and opposed to take a loan because he had to pay interest. A request to be exempted from paying interest had been denied. He summed up his situation:

'I have fallen into this trap of taking the land twelve years ago. I thought it was paradise and this was my chance to have a secure life for my children. But I discovered that I need to spend a lot [of money] on the land before it gives anything and this is difficult when I have children to support and I do not have a second source of income'.

In order to counter that graduates become 'bound to the soil' with no possibility to leave the new lands, the Egyptian Parliament passed the so-called 'Investment Law' in 2002. According to this, graduates are entitled to sell their land. Until 2002, graduates could not sell their land, but many rented it out on more or less legal terms. As some rented their land out to other graduates and left the villages all together, it led to absenteeism. The new law entitles graduates to sell their land to investors or other interested buyers with a transition period of ten years in terms of being the hiyaza owner. This means that the buyer cannot become member of the agricultural cooperative, attend training courses, or take loan in the land for the first ten years. Hence, the investment law is made to alleviate the problems for the graduates who were caught in a poverty trap in the new lands and not to provide a new land market for investors. Nevertheless, by implementing the investment law, the Egyptian Government has taken a step towards solving the problems regarding the transfer of land and absenteeism that have been pointed out both by people involved in the project and by researchers (e.g. Meyer, 1998).

\section{Discussion and concluding remarks}

As stressed in the first part of the paper, it is important to consider the Egyptian Governments' land reclamation projects in the context of its wider agricultural and economic policies. It can be concluded that land reclamation has been on the political agenda since the 1950s and used as a remedy for a variety of problems e.g. desertification, alleviation of poverty, and reduction of graduate unemployment. As argued by Bush (2002b, 2007) and 
Mitchell (1995), the Governments' land reclamation projects have provided opportunity to take the 'eye off the ball' of the old lands, of land distribution as well as market liberalisation, and the role of donors and international investors.

Especially, international donors have been vital for the economics of desert development projects such as the Mubarak Project. The cooperation with Israel is a case in point. Since the Egyptian and Israeli signing of the Camp David Accords in 1978 and the subsequent Peace Treaty in 1979 agricultural cooperation within the field of agriculture has been important (Adriansen, 2005). Peace for the Government of Egypt it is a balancing act between the peace treaty emphasising normal neighbouring relations and the Camp David Accords calling for a durable solution to the Palestinian problem. The government is handling this balancing act by engaging in close cooperation within desert agriculture while dismissing most other types of cooperation and even trade. The international donor community, e.g. USAID, ICARDA, and Danida, has been eager to support this cooperation in attempt to further peace in the Middle East. ${ }^{21}$

Especially the new lands in the Western desert along the Alexandria-Cairo desert highway (see Fig. 1) have become the demonstration site for the 'greening of the desert' with Nubariya as the epicentre. In an interview with the Israeli Foreign Minister, Moshe Arens, on Israel Television (Arabic Service), 22 February 1989, the minister described the cooperation in the Western desert this way (Israeli Ministry of Foreign Affairs, 1989):

'I would first of all like to say that the most impressive part for me in the visit was the visit in Nubariya, where there I saw cooperation between Israelis and Egyptians in an important area: making the wilderness bloom on a very large scale. If we had a monopoly in Israel, then I think the Egyptians are taking the monopoly away from us. But, with Israeli technological assistance, with the assistance of Israeli specialists, one can see 'beautiful Eretz Yisrael' in Egypt, along the Cairo-Alexandria highway'.

While the Egyptian government has claimed that it has undertaken the extensive land reclamation programme as part of the initiative put forward by President Mubarak, "to put an end to Egypt's dependence on foreign countries" (El-Mowelhi et al., 1996), reclamation of desert lands - at least in the Western desert - has in fact taken place under considerable Israeli influence. And many of the projects would not have been economically feasible without massive international investments - often given under the pretext of furthering peace in the region (Adriansen, 2003).

This is just one example of how land reclamation cannot be understood in isolation from the wider political and economic context. Other researchers have also questioned the economic sustainability of the reclamation projects (e.g. Bush, 2007). And especially the agro-ecologically sustainability of reclaiming the desert has been questioned (e.g. Enien et al., 2000; Kamel and Dahl, 2005; Lenny et al., 1996; Monem et al., 1998). Nevertheless, desert reclamation continues.

Considering the long duration of land reclamation policies and projects, it is surprising how little has been written and notably how few field studies have been made in the new lands. The development of desert villages has provided (and will provide) a significant number of people not only with new agricultural lands and improved housing, but also with new opportunities for making a living. It is on this backdrop that the paper examined the life in the new lands in order to understand how the new settlers perceive life in the new lands.

\footnotetext{
21 I have shown elsewhere (Adriansen, 2003, 2005) how the Egyptian Government receives international aid for desert development under the condition that the aid is used in collaboration with Israel. The Trilateral Training Programme financed by Danida is a case in point.
}

The fieldwork attempted to highlight the complex amalgam of social, economic, cultural, and natural processes bound up with the physical and socio-cultural construction of these desert villages. In order to sum up the settlers' lives of the new lands, we can consider two images: To perceive the new lands as 'spaces of opportunity' is linked with an idea of desert villages as the last frontier. People have chosen to live here because they see it as a national project to turn the desert green, or they use a religious discourse as justification for the migration to find a new refuge. They are attracted by the possibility of becoming landowners and they negotiate and redefine the social norms and rules of the old lands. This is an image of people actively shaping their own life. In contrast to this, the perception of the new lands as 'spaces of exploitation' links to the idea of these areas as a margin; here the inhabitants feel marginalised by the government and they feel left in poverty in the middle of nowhere. The migration to the desert villages is due to lack of other opportunities, or people claim that they have been deceived to believe that they were offered a new opportunity when in fact all they are being exploited in a remote area. This is an image of people passively being impoverished.

Problems regarding transfer of land and absenteeism are not unique for the Mubarak Project. As mentioned by Wen (1979), issues such as absenteeism, transfer of land, and optimal holding size are almost inherent problems in any human settlement programme. In the Egyptian case, the investment law has allowed transfer of land and this has opened for a new land market in the villages. Nevertheless, illegal forms of tenancy still takes place and a number of families live as tenants in the graduate villages with few rights and the risk of having to leave with few days notice.

The impression from the fieldwork was that the positive image was by far most prevalent, but the majority of the inhabitants although by and large satisfied with their new life - wished that government services especially schools would be improved. There some obvious solutions to some of these problems. For instance some of the educated spouses could be granted public office in the villages, for instance as teachers in the local school. Also, the majority of the training courses and activities aimed at the settlers appear to have a quite narrow agricultural focus and little emphasis on capacity building vis-à-vis village development. Finally, it should be noticed that many women have managed to make the most of the new opportunities in the new lands. Notably, the World Food Programme has shown how empowerment of women can be approached by simple means. All of these issues are important to keep in mind when planning and implementing large reclamation projects such as Toshka.

Moving to the new villages entails both a loss of close connection to the old community and the opening of new horizons. In the words of Crang: 'It is important to recognise that along with the loss of organic communities come new freedoms, new opportunities and excitements - the chance to escape the claustrophobia sometimes produced in closed societies, the possibilities of chance encounters and new experiences' (1998, p. 118). Many of the new settlers do perceive their new status as land owners as an opportunity and yet they complain about lack of services; and there seems to remain a lot to be done in that area. Even worse, some of the villages have inadequate supply of (irrigation) water, which makes cultivation and thus the whole life in the villages very difficult. Twenty years ago, Hopkins et al. made a characterisation of the problems and attitudes of the settlers that still applies:

‘... although people by and large see the government as the source of all their problems, they also commonly suggest that the government is the source of the solution to all their problems. The people are alienated but eternally hopeful'

(Hopkins et al., 1988, p. 121). 
Although there are still many questions to be answered, it is the hope that this paper will provide lessons that can be used when planning development of new settlements either in other reclaimed lands or elsewhere.

\section{Acknowledgements}

The paper is based on fieldwork in reclaimed lands in Lower Egypt in 2002-2006. The interviewed inhabitants of the new lands were promised confidentiality, so they will not be mentioned. However, I am indebted to them for having shared their time and knowledge with me. The work was carried out in collaboration with the Desert Development Center at the American University in Cairo. I wish to thank Dr. Richard Tutwiler, director of DDC, for facilitating my work and providing constructive comments on this paper. The fieldwork would not have been possible without the helpful and friendly support from the employees at DDC, especially Mohsen Nawarra who helped out during difficult situations in the field. Last but not least thanks are due to Nagwa Hassan, my assistant and friend who proved invaluable in the 'lush Egyptian desert'. All the usual disclaimers apply.

\section{References}

Abdel-Khalek, G., 2002. Stabilization and adjustment in Egypt: sequencing and sustainability. In: Bush, R. (Ed.), Counter-Revolution in Egypt's Countryside: Land and Farmers in the Era of Economic Reform. Zed Books, Malaysia, pp. 32 54.

Adriansen, H.K., 2003. Greening the desert: Egyptian-Israeli cooperation during the cold peace. In: Presentation for MESA Annual Meeting, Anchorage, 9th of November.

Adriansen, H.K., 2005. Egyptisk-israelsk samarbejde under den "kolde fred". In: Adriansen, H.K., Malmvig, H. (Eds.), Mellemøsten: Lokalt, Regionalt og Internationalt. DIIS, Copenhagen, pp. 103-117.

Adriansen, H.K., 2007. Rural Childhoods in Egypt's Desert Lands. DIIS Working Paper

Agnew, J., 2005. Space. Place. In: Cloke, P., Johnston, R. (Eds.), Spaces of Geographical Thought: Deconstructing Human Geography's Binaries. Sage, Noida, pp. 81-96.

Ansell, N., van Blerk, L., 2007. Doing and belonging: toward a more-thenrepresentational account of young migrant identities in Lesotho and Malawi. In: Panelli, R., Punch, S., Robson, E. (Eds.), Global Perspectives on Rural Childhood and Youth. Routledge, USA, pp. 17-28.

Ayeb, $\mathrm{H} ., 2002$. Hydraulic politics: the Nile and Egypt's water use: a crisis for the twenty-first century? In: Bush, R. (Ed.), Counter-Revolution in Egypt's countryside: Land and Farmers in the Era of Economic Reform. Zed Books, Malaysia, pp. 76-100.

Bach, K.H., 1997. The descendants of the Qaadi and other villagers: social reproduction, structures and practices in an Egyptian village. Ph.D. Dissertation, University of Copenhagen. Ph.D. række nr. 8. Institut for Antropologi, 1998.

Bach, K.H., 1998. The vision of a better life: new patterns of consumption and changed social relations. In: Hopkins, N.S., Westergaard, K. (Eds.), Directions of Change in Rural Egypt. The American University in Cairo Press, Egypt, pp. 184200.

Bach, K.H., 2002. Rural Egypt under stress. In: Bush, R. (Ed.), Counter-Revolution in Egypt's Countryside: Land and Farmers in the Era of Economic Reform. Zed Books, Malaysia, pp. 159-184.

Bush, R. (Ed.), 2002a. Counter-Revolution in Egypt's Countryside: Land and Farmers in the Era of Economic Reform. Zed Books, Malaysia.

Bush, R., 2002b. Land reform and counter-revolution. In: Bush, R. (Ed.), CounterRevolution in Egypt's Countryside: Land and Farmers in the Era of Economic Reform. Zed Books, Malaysia, pp. 1-31.

Bush, R., 2002c. More losers than winners in Egypt's countryside: the impact of changes in land tenure. In: Bush, R. (Ed.), Counter-Revolution in Egypt's Countryside: Land and Farmers in the Era of Economic Reform. Zed Books, Malaysia, pp. 185-210.

Bush, R., 2004. Civil Society and the Uncivil State: Land Tenure Reform in Egypt and the Crisis of Rural Livelihoods. UNRIDS Civil Society and Social Movements Programme Paper Number 9.

Bush, R., 2007. Politics, power and poverty: twenty years of agricultural reform and market liberalisation in Egypt. Third World Quarterly 28 (8), 1599-1615.

Bushin, N., Ansell, N., Adriansen, H.K., Lähteenmaa, J., Panelli, R., 2007. Reflecting on contexts and identities for young rural lives. In: Panelli, R., Punch, S., Robson, E. (Eds.), Global Perspectives on Rural Childhood and Youth. Routledge, USA, pp. 69-80.

Crang, M., 1998. In: Cultural Geography. Routledge Contemporary Human Geography. Routledge, Padstow.
Dyer, G., 1991. Farm size-farm productivity reexamined: evidence from rural Egypt. Journal of Peasant Studies 19 (1), 59-92.

EHDR, 2003. Egypt Human Development Report. United Nations Development Programme, Institute of National Planning, Cairo, Egypt.

El-Din, G.E., 2000. Toshka in the crossfire. Al Ahram Weekly 27 Jan. - 2 Feb. 2000, Issue No. 466. <http://weekly.ahram.org.eg/2000/466/eg7.htm> (accessed 05.07.07.).

El-Din, G.E., 2006. Parliament to scrutinize Toshka. Al Ahram Weekly 6-12 April. 2006, Issue No. 789. <http://weekly.ahram.org.eg/2000/466/eg7.htm> (accessed 28.09.08.)

El-Mowelhi, N., Abt, Y., Herman, Z., 1996. Project Proposals for Collective Agricultural and Rural Development of Settlement in Nubariya Region, Egypt. MASHAV, Centre for International Cooperation. August 1996.

El-Sayed, M., 2007. Mega money losers. Al Ahram Weekly 12-18 April 2007, Issue No. 840. <http://weekly.ahram.org.eg/2007/840/ec3.htm> (accessed 28.09.08.).

El-Zoghby, S.M., 1999. Sustainable planning of desert land reclamation projects in Egypt as related to drought management: an integrated strategy. In: Paper Presented at the International Conference on Integrated Drought Management, arranged by UNESCO, 20-22 September 1999, Pretoria, South Africa.

Enien, R.R., Sharif, A.A., Monem, M.A., Kamel, A., Solh, M.B., Bedier, M., Khalifa, H., 2000. A new research paradigm for sustainable agriculture in Egypt. Experimental Agriculture 36 (2), 265-271.

Erian, W.F., 1997. The use of sustainable development multi-indicators for evaluating the stabilization in some new rural communities in desert areas of Egypt. In: Paper Presented at the International Conference on Geo-Information for Sustainable Land Management, Enschede, 17-21 August.

FAO, 2006. Food and agriculture indicators. Country: Egypt. <http://www.fao.org/ es/ess/compendium_2006/pdf/EGY_ESS_E.pdf> (accessed 28.09.08.)

FAO (n.d.) Gateway to national information on land, water and plant nutrition: Egypt, land resources. <http://www.fao.org/ag/AGL/swlwpnr/reports/y_nf/ egypt/home.htm> (accessed 05.07.07.).

Glavanis, K.R.G., Glavanis, P.M., 1983. The sociology of agrarian relations in the middle east: the persistence of household production. Current Sociology 31 (2), $1-110$.

Hammar, A., 2002. The articulation of modes of belonging: competing land claims in Zimbabwe's Northwest. In: Juul, K., Lund, C. (Eds.), Negotiating Property in Africa. Heinemann, USA, pp. 211-246.

Holmén, H., 1991. In: Building Organizations for Rural Development: State and Cooperatives in Egypt. Meddelanden Från Lunds Universitets Geografiska Institutioner, Avhandlingar, vol. 113. Lund University Press, Sweden.

Hopkins, N.S., 1997. Small farmer households and agricultural sustainability in Egypt. In: Hopkins, N.S., Ibrahim, S.E. (Eds.), Arab Society: Class Gender, Power and Development. The American University in Cairo Press, Egypt.

Hopkins, N.S., Westergaard, K. (Eds.), 1998. Directions of Change in Rural Egypt. The American University in Cairo Press, Egypt.

Hopkins, N. et al., 1988. Participation and community in the Egyptian new lands: the case of South Tahrir. Cairo Papers in Social Science 11 (1).

Ibrahim, F.N., Ibrahim, B., 2003. Egypt: An Economic Geography. I.B. Tauris, Bodmin.

IFAD, 2000. Report to the conference of the parties fourth session (COP-IV) on implementation of the convention to combat desertification: IFAD-supported activities in the Near East and North Africa Region relevant to CCD implementation. <http://www.unccd.int/cop/reports/africa/un/2000/ifadeng.pdf> (accessed 05.07.07.).

Israeli Ministry of Foreign Affairs, 1989. Interview with Foreign Minister Arens on Israel Television-Arabic Service-22 February 1989. <http://www.mfa.gov.il/ MFA/Foreign\%20Relations/Israels\%20Foreign\%20Relations\%20since\%201947/ 1988-1992/20\%20Interview\%20with\%20Foreign\%20Minister\%20Arens\%20on\%20Israel> (accessed 03.05.09.).

Johnson, A.J., 2004. Restructuring Rural Egypt: Ahmed Hussein and the History of Egyptian Development. The American University in Cairo Press, Egypt.

Johnston, R.J., 2000. Community. In: Johnston, R.J., Gregory, D., Pratt, G., Watts, M. (Eds.), The Dictionary of Human Geography. Blackwell, Padstow, pp. 101102

Kamel, S., Dahl, C., 2005. The economics of hybrid power systems for sustainable desert agriculture on Egypt. Energy 30 (8), 1271-1281.

Lenny, M.P., Woodcock, C.E., Collins, J.B., Hamdi, H., 1996. The status of agricultural lands in Egypt: the use of multitemporal NDVI features derived from Landsat TM. Remote Sensing of Environment 56, 8-20.

MALR, 2000. Mubarak national scheme for settling and developing newly reclaimed lands. Publication from the Egyptian Ministry of Agriculture and Land Reclamation, May.

MALR, 2003. Information on the size of public land reclamation by the Egyptian Ministry of Agriculture and Land Reclamation compiled by Kheiry Sherif, Ministry of Agriculture and Land Reclamation 20/10/03.

Meyer, G., 1978. Erschliessung und entwicklung der ägyptischen neulandsgebiete. Erdkunde 32, 212-227.

Meyer, G., 1994. Land reclamation and development of new agricultural land in Egypt. Applied Geography 44, 59-71.

Meyer, G., 1995. Liberalisierung and privatisierung der ägyptischen landwirtschaft. Erdkunde 49, 17-31.

Meyer, G., 1998. Economic changes in the newly reclaimed lands: from state farms to small holdings and private agricultural enterprises. In: Hopkins, N.S. Westergaard, K. (Eds.), Directions of Change in Rural Egypt. The American University in Cairo Press, Egypt, pp. 334-356.

Mitchell, T., 1995. The object of development: America's Egypt. In: Crush, J. (Ed.), Power of Development. Routledge, Padstow, pp. 129-157. 
Mitchell, T., 1998a. The market's place. In: Hopkins, N.S., Westergaard, K. (Eds.), Directions of Change in Rural Egypt. The American University in Cairo Press, Egypt, pp. 19-40.

Mitchell, T., 1998b. Fixing the economy. Cultural Studies 12 (1), 82-101.

Monem, M.A.S.A., Khalifa, H.E., Solh, M.B., 1998. Building and sustaining high production capacity of Egypt's irrigated lands: a long-term research program. Journal of Sustainable Agriculture 11 (2-3), 7-18.

Morley, D., 2001. Belongings: place, space and identity in a mediated world. Cultural Studies 4 (4), 425-448.

Müller-Mahn, D., 1998. Spaces of poverty: the geography of social change in rural Egypt. In: Hopkins, N.S., Westergaard, K. (Eds.), Directions of Change in Rural Egypt. The American University in Cairo Press, Egypt, pp. 256276.

Razavi, S., 2007. Liberalisation and the debates on women's access to land. Third World Quarterly 28 (8), 1479-1500.

Saad, R., 1998. The organization of work and production and the role of participation in Qena and Aswan. Qualitative research, final report. The Social Research Center, American University in Cairo.

Saad, R., 1999. Agriculture and politics in contemporary Egypt: the 1997 tenancy crisis. Cairo Papers in Social Science 22 (4), 22-35.

Saad, R., 2002. Egyptian politic and the tenancy law. In: Bush, R. (Ed.), CounterRevolution in Egypt's Countryside: Land and Farmers in the Era of Economic Reform. Zed Books, Malaysia, pp. 103-125.
Scudder, T., 1991. A sociological framework for the analysis of new land settlements. In: Cernea, M.M. (Ed.), Putting People First: Sociological Variables in Rural Development. Oxford University Press, Oxford, pp. 148-187.

Seddon, D., 1986. Commentary on agrarian relations in the Middle East: a 'new paradigm' for analysis? Current Sociology 34 (2), 151-172.

Springborg, R., 1979. Patrimonialism and policy making in Egypt: Nasser and Sadat and the tenure policy for reclaimed lands. Middle Eastern Studies 15 (1), 49-69.

Tuan, Y.E., 1977. Space and Place. Arnold, London.

UNCCD, 2005. Egyptian National Action Program to Combat Desertification. UNCCD together with the Egyptian Ministry of Agriculture and Land Reclamation and the Desert Research Center. June 2005. <http://www.unccd.int/ actionprogrammes/africa/national/2005/egypt-eng.pdf> (accessed 28.09.08.).

UNDP, 2003. Arab Human Development Report 2003: Building a Knowledge Society. National Press, Jordan.

Voll, S., 1980. Egyptian land reclamation since the revolution. The Middle East Journal 34 (2), 127-148.

Wen, G., 1979. Community building programs of human settlement on new lands. In: El-Hamamsy, L., Garrison, J. (Eds.), Human Settlements on New Lands: Their Design and Development. The American University in Cairo Press, Malta, pp. 33-50.

Wolff, P., 1993. Land reclamation in Egypt. Tropenlandwirt 94, 103-117. 